\title{
Losing a language in childhood: a longitudinal case study on language attrition*
}

\section{CRISTINA FLORES}

University of Minho, Portugal

\begin{abstract}
This paper is based upon a longitudinal study of L2 attrition in a bilingual child who grew up in an L2 migration background (Germany) and moved to the country of origin (Portugal) at the age of nine, experiencing a dominance shift from the L2 to the L1. The study aims to analyze effects of language loss in L2 German. Data collection started three weeks after the child's immersion in the Portuguese setting and ended 18 months later. Results show first effects of language attrition after five months of reduced exposure to German; 18 months later the informant showed severe word retrieval difficulties and was unable to produce complete sentences in her L2. The findings thus confirm the conclusions of other studies on child language attrition, which attest to strong effects of attrition when the loss of contact with the target language occurs in childhood.
\end{abstract}

Keywords: Language attrition, bilingualism, German, European Portuguese

* This article was published in Journal of Child Language

Reference:

Flores, Cristina (2014). Losing a language in childhood: a longitudinal case study on language attrition. Journal of Child Language. DOI: 10.1017/S0305000914000233. http://journals.cambridge.org/action/displayAbstract?fromPage=online\&aid=9305320\&fileId=S 0305000914000233 


\section{Introduction}

The loss of a language acquired in childhood as the L1 or L2 is a socio- and psycholinguistic phenomenon that may occur if a bilingual speaker experiences a significant change in the degree and the type of input from one of his/her languages. In current linguistic research this phenomenon is known as language attrition. According to Seliger (1996: 106), language attrition is the “temporary or permanent loss of language ability as reflected in a speaker's performance or in his or her inability to make grammaticality judgments that would be consistent with native speaker monolinguals at the same age and stage of language development."

The social context in which language attrition tends to occur nowadays is migration. A child who grows up monolingual in his/her country of origin and moves with his/her family to a country where another language is officially spoken will typically acquire the new language as the L2 and become bilingual without much effort. However, the change of the dominant linguistic environment not only means that the child will be exposed to a new language, but also that the exposure to the language of origin, i.e., the heritage language, will become more limited since the use of the L1 is generally restricted to communication within the family. Studies on language attrition in childhood have shown that, in these situations, the acquisition of the L2 may co-occur with the decline of L1 proficiency, affecting not only the child's lexical competence but also his/her morphosyntactic knowledge (Kaufman \& Aronoff, 1991; Polinsky, 2011; Turian \& Altenberg, 1991). 
In the research field of language attrition, less attention has been given to situations in which the L1 input becomes dominant again after a more or less extended period of L2 dominance. This may happen in the case of remigration, i.e., when children who grow up bilingually in a context of migration return to their country of origin. Normally, in these cases, the dominant language of the child before return is the language of the host country (the L2), but after moving back to the L1 context s/he loses daily L2 input and erosion effects tend to appear a few months later (see articles in Hansen, 1999). The distinctiveness of this situation is that we are dealing with the attrition of a majority language which was the dominant language, rather than the actual native language of the child. We already know that in child language attrition the age of onset of input loss and the amount of contact with the attrited language after the input shift are two main predictors of language loss. The younger the speaker and the lesser the input, the more likely attrition effects will appear (Montrul, 2008). Studies on L2 attrition may reinforce the importance of a third predictor: the context of language acquisition. The effects of language attrition seem to be even more severe if the attrited language was acquired in an L2 setting, even though it became the dominant language of the child before the change of environment (Flores, 2010). This assumption is consistent with the theoretical claim that child L2 acquisition differs from L1 acquisition in terms of the course, rate and uniformity of the acquisition of various grammatical properties (Meisel, 2011), even if L2 speakers who acquired their L2 in childhood are able to achieve, ultimately, a native-like state of acquisition. Thus, it is rational to assume that these properties might also be especially vulnerable in contexts of L2 attrition. 
This article presents a case study on child language attrition which fits in the latter description. The participant, Ana, grew up in Germany as the youngest child of a Portuguese migrant family. At the age of 9;05 Ana returned to Portugal with her mother and her older brother. When she lived in Germany, Ana was highly proficient in German, the language of the dominant environment, and in Portuguese, the home language. After returning to Portugal, exposure to German was drastically reduced and Portuguese became Ana's dominant language. This study analyzes the development of the participant's proficiency in German from the moment of arrival in Portugal until 18 months later, focusing on morphosyntactic properties such as subject expression, verb placement, case and gender marking, and verb morphology in German.

\section{Summary of previous studies on $\mathrm{L} 2$ attrition in the context of remigration}

Some studies have already applied a longitudinal methodology in order to document the onset of attrition in cases where a child moves from one linguistic environment into another and experiences changes in linguistic input (Bingham, 2007; Kang, 2011; Kaufman \& Aronoff, 1991; Kuhberg, 1992; Olshtain, 1986; Reetz-Kurashige, 1999; Tomiyama, 2000; Yoshitomi, 1994). However, the studies differ in several points such as the context of acquisition, the age of input change, the degree of exposure to the attrited language, the period of observation and the language pairs under investigation. Despite these differences, a common observation is found in all studies: if a bilingual speaker loses contact with one language during childhood, attrition effects appear within the first 15 months after the input conditions have changed. In particular, studies focused on language attrition in the context of remigration report a significant decline of language proficiency, even though the speakers seem to show native-like performance at initial stages of observation. This is certainly related to the fact that the language under observation was acquired as a second language and not as the native language of the speakers. 
The study which mostly resembles the present investigation is Kuhberg's (1992) study of two Turkish-German bilingual children, who grew up in Germany, the L2 migration setting, and moved to Turkey, their parents' home country, at the ages of nine and seven. The period of observation started one month after return and lasted for 15 months in the case of the older girl and 20 months in the case of the younger one. The study was interrupted because the girls became ashamed of their German and refused to speak it any longer. Turkish had become their dominant language. Kuhberg (1992) reports three different stages of decline, starting at an initial period marked by native-like fluency in L2 German. In the second stage, which begins approximately five months later, the informants show first effects of attrition. Their speech is less fluent and contains several instances of code-switching, as well as errors in the use of verbs, articles and prepositions. The third stage is marked by a high degree of attrition affecting lexicon, morphology and syntax. The girls show severe word retrieval difficulties; they avoid the use of pronouns; in nominal morphology, they mark number and case with Turkish suffixes; verbs are no longer correctly inflected and the Turkish word order (SOV) is transferred to German root sentences. One of the most interesting observations of this study is the fact that both children (who are not related) go through similar stages of proficiency decline.

Olshtain (1986) also focuses on L2 attrition in the context of remigration. The author reports the findings of three longitudinal studies involving children born to Hebrew-speaking parents who returned to Israel after having spent a long period of time in an English-speaking country. The participants (aged between five and 14) were tested periodically during six to 12 months. Several features of language attrition were discovered, especially in the younger children (five to eight-year olds), who exhibited severe word retrieval difficulties even six months after return. Besides problems with the use of prepositions, the regularization of irregular verbs and the use of incorrect tense forms, Olshtain also found attrition effects in word order. 
Tomiyama (2000) observed an eight-year-old boy who had lived in the USA for nearly seven years and then returned with his parents to Japan, his home country. As in the previous studies, until remigration the L1 was not the dominant language of the child. However, after a few months back in Japan, dominance shifted and his L2 English started to show signs of attrition which resemble the effects mentioned in other studies on child L2 attrition. The author described structural changes in morphosyntactic domains such as word order and nominal or verb morphology.

Flores $(2010,2012)$ analyzed attrition effects in bilingual second-generation migrants who grew up in a German-speaking country and moved to Portugal at different ages, having lost regular input of German. Based on a cross-sectional methodology, these studies compared different groups of speakers according to their age of return, focusing on their knowledge of German verb placement and object expression. The results showed that attrition effects were very extensive in speakers who had come to Portugal in pre-puberty age, even though their length of residence was significantly lower than that of older returnees. Although the data reinforced the importance of age in language retention, the cross-sectional methodology did not allow us to follow the process of decline from the onset of attrition.

The present study will fill this gap by collecting data longitudinally from the moment of return up to 18 months later. It further aims to give new contributions to the general debate on child language attrition by investigating a language pair which has not been studied to date (Portuguese and German) and by focusing on the particular case of language decline in a context where the dominant language of the informant was not the native language.

\section{Some remarks on German and Portuguese syntax and morphology}

A comparison between studies on language attrition in German (e.g., Schmid, 2002) and research on German L2 acquisition (see articles in Ahrenholz, 2006) shows that certain properties of German grammar appear to be particularly vulnerable in both types of language development. Some of these properties were selected for the present study since the language under analysis is 
the informant's L2 (although it became her dominant language). Hereafter, we will briefly describe those properties and justify why they were chosen.

\section{Verb placement}

German is characterized by the verb-second (V2) effect and verb final placement, two constructions which distinguish this Germanic language from Romance languages such as Portuguese.

In root sentences German displays the V2 word order. This means that the finite verb moves to the second position of the sentence, preceded by only one phrase which may be the subject (giving rise to the SVO order, i.e., the default order of Portuguese sentences) or a non-subject constituent, e.g., a fronted object or an adverbial phrase (see example (1a)). When the initial position is occupied by such a non-subject element, the subject of the sentence comes after the verb, resulting in the XPVS order.

In embedded clauses, in turn, the verb remains in its base position at the end of the sentence, resulting in the SOV order, as in (1b). According to a more classical generative view of German syntax, the verb-final position in embedded clauses is linked to the fact that the verb phrase (VP) and the inflectional phrase (IP) are head-final projections.

The V2 effect and the fact that VP and IP are head-final projections are also visible in the word order of complex verb forms. In these cases, the finite verb is in V2 position, but the non-finite verb form is at the end of the sentence, which leads to a discontinued vOV order (example 1c).

(1) a. Gestern kaufte Ana ein neues Auto.

yesterday bought Ana a new car

'Yesterday Ana bought a new car.'

b. Ich denke, dass Ana heute ein neues Auto kauft.

I think that Ana today a new car buys 
'I think that Ana will buy a new car today.'

c. Morgen wird Ana ein neues Auto kaufen.

tomorrow will Ana a new car buy

'Tomorrow Ana will buy a new car.'

The canonical word order in Portuguese is SVO in main and subordinate clauses. Thus the verb is in the third position in the respective Portuguese examples (see $2 \mathrm{a}$ and $2 \mathrm{~b}$ ). In complex verb constructions, the infinitive form immediately follows the finite one (2c). This would be ungrammatical in German in all three cases.

(2) a. Ontem a Ana comprou um carro novo.

yesterday the Ana bought a car new

'Yesterday Ana bought a new car.'

b. Eu penso, que a Ana amanhã comprará um carro novo.

I think that the Ana tomorrow buys a car new

'I think that Ana will buy a new car tomorrow.'

c. Morgen a Ana vai comprar um carro novo.

tomorrow the Ana will buy a car new

'Tomorrow Ana will buy a new car.'

Research on L1/L2 attrition (Kuhberg, 1992; Schmid, 2002) as well as adult and child L2 acquisition of German (Clahsen, Meisel \& Pienemann, 1983; Rothweiler, 2006) has shown that deviations to verb-second and verb-final placement are typical errors of speakers who are acquiring or losing the German language. Based on these observations and on Flores' $(2010,2012)$ results, the present study will analyze Ana's proficiency with respect to verb placement in main and subordinate clauses as well as in discontinued complex verb forms. 


\section{Subject expression}

Subject expression will be further investigated. In contrast to Portuguese, which is a typical nullsubject language, German is a non-pro-drop language. This means that, except in very limited contexts, German generally does not allow for the omission of the subject, nor for the occurrence of null expletives. In the following sentences, for instance, the realization of the first-person pronoun is mandatory in German (see 3a), whereas in Portuguese that pronoun may either be realized (3b) or omitted (3c).

(3) a. Heute will ich nicht lesen.

today want I not read

'Today I don't want to read.'

b. Hoje eu não quero ler.

today I not want read

c. Hoje Ø não quero ler.

today not want read

'Today I don't want to read.'

Unlike German verb placement, subject expression is a linguistic domain where syntax interacts with pragmatics. Research on bilingual language acquisition and attrition has suggested that bilingual speakers may show more difficulties in acquiring or processing certain aspects of grammar set at the interface with other cognitive subsystems (e.g., the syntax-discourse interface) than «narrow» grammatical aspects. Those interface properties thus remain a constant locus of transfer (Sorace, 2004). Tsimpli, Sorace, Heycock and Filiaci (2004), for instance, have shown that subject expression is particularly vulnerable in cases of language attrition and remains difficult to master even at near-native stages of L2 acquisition.

If interface properties are indeed less stable than purely syntactic properties, this should be visible in the process of proficiency decline. Therefore the nature of the properties under analysis 
should allow us to test if the Interface Hypothesis proposed by Sorace and colleagues also applies to child attrition.

In the morphological domain, we will focus on case and gender marking as well as verb inflection (person and number). Nominal number marking and verb tense will be excluded due to the reduced number of plurals and different tense forms in the data base.

\section{Nominal morphology}

Gender and case marking are two key features of German morphology which make the nominal inflection system quite complex.

German has a four-case system, which comprises the nominative, the accusative, the dative and the genitive cases. In nominal phrases, the case can be marked on the determiner (4a and 4b); on both the determiner and the noun through an inflectional morpheme (4c); or also on the attributive adjective (4d). Personal pronouns have special forms for different cases [e.g., dir ('you ${ }^{\mathrm{DAT}}$ ') in example (4b)].

(4) a. Der Ball ist ziemlich alt.

the $e^{\text {Nom }}$ ball is very old

'The ball is very old.'

b. Ich leihe dir den Ball heute.

I lend you ${ }^{\text {DAT }}$ the ${ }^{A C C}$ ball today

'I will lend you the ball today.'

c. Wegen des Wetters bleibe ich heute zu Hause.

due the ${ }^{G E N}$ weather stay I today at home

'Due to the weather I will stay at home today. '

d. Ich fahre heute mit meinem neuen Auto in die Arbeit.

$I$ drive today with my $y^{D A T}$ new $w^{D A T}$ car to the $e^{A C C}$ work 
'Today I will drive to work in my new car.'

In Portuguese, vestiges of case marking are only visible in the clitic system (where the pronouns $a$ [fem.] / $o$ [masc.] mark the accusative and lhe the dative case). No other overt case marking forms can be found. So, unlike the German examples (4a) and (4b), in Portuguese the NP a bola ('the ball') remains unaltered as both subject and direct object (see $5 \mathrm{a}$ and $5 \mathrm{~b}$ ).

(5) a. A bola é muito velha.

the ball is very old

'The ball is very old.'

b. Eu empresto-te a bola hoje.

I lend you the ball today

'I will lend you the ball today.'

Studies on language attrition and language change in languages with a rich case system have shown that case marking tends to be highly affected by the phenomena of language contact and deprivation (Altenhofen, 1996; Boas, 2009; Jordens, de Bot \& Trapman, 1989; Polinsky, 1997, Schmid, 2002). Some studies attest to a clear tendency of overall reduction of the case system toward a simpler system (e.g., Altenhofen, 1996; Boas, 2009; Polinsky, 1997); others observe mistakes in the use of all cases, thus not confirming the overuse of the two cases claimed to be simpler, i.e., the nominative and the accusative (Jordens et al., 1989; Schmid, 2002). More specifically, studies on language change that focus on varieties of German spoken by German immigrants in non-European countries, such as Texas German or Hunsrückisch in South Brazil, have confirmed the overall replacement of the dative case by the nominative and the accusative (Altenhofen, 1996; Boas, 2009). Interestingly, a similar tendency for replacing the dative by other cases is also observed in child L2 acquisition (Wegener, 1995b). 
The German gender system is also a highly complex inflectional system. Unlike Portuguese, which is a two-gender language, German has three grammatical genders: masculine, feminine and neuter. Gender is inherently assigned to the noun, but - except some suffixes with defined genders - German lacks gender morphemes, so there are almost no clues as to the gender of a noun. It has to be acquired as a lexical entry together with the noun. The lexical gender of the noun becomes clear from the articles (6a), the pronouns (6b) and the attributive adjectives (6c).

(6) a. Der Garten ist wunderschön!

the ${ }^{\text {MAS }}$ garden is wonderful

'The garden is wonderful!'

b. Meine Tasche ist neu.

$m y^{F E M}$ bag is new

'My bag is new.'

c. Ein altes Haus stand hier vorher.

$a n^{\text {NEUT }}$ old ${ }^{N E U T}$ house stood here before

'An old house stood here before.'

In Portuguese gender is marked on the (definite or indefinite) article, on pronouns and on (attributive and predicative) adjectives. Many nouns also display a canonical gender morpheme (-o $/-a)$

(7) A minha bolsa é nova e combina com o meu vestido preto.

the $e^{\text {FEM }} m y^{\text {FEM }}$ bag $^{\text {FEM }}$ is new $w^{\text {FEM }}$ and fits $\quad$ with the ${ }^{\text {MAS }}$ my $y^{\text {MAS }}$ dress $^{\text {MAS }}$ black $^{\text {MAS }}$

'My bag is new and it fits with my black dress.'

The German gender system is indeed more complex than the Portuguese one: while both languages have feminine and masculine genders, German further includes the neuter, which has no 
equivalent in Portuguese. As with case marking, this means that the stronger language (Portuguese) is less complex than the attrited one. A possible outcome of this language contact could be the reduction of German toward a two-gender system, without the neuter. However, unlike case marking, research on language attrition and L2 acquisition of German does not find clear evidence of the reduction of the gender system, but a tendency to assign gender on a random basis (Schmid, 2002; Wegener, 1995a).

\section{Verb inflection}

Finally, verb inflection will also be analyzed. In addition to tense and mood, which will not be discussed in this paper, German verbs are inflected for person and number (first, second and third person; singular, plural). There is one conjugational pattern for the present tense (8a) and two patterns for the past tense, which depend on the verb type [strong (8b) and weak verbs (8c)]. Only some auxiliaries do not follow these patterns.

$\begin{array}{cccc}\text { (8) } & \text { a. } \text { kommen (to come) } & \text { b. geben (to give) } & \text { c. leben (to live) } \\ \text { ich (I) } & \text { komme } & \text { gab } & \text { lebte } \\ \mathrm{du}(\text { you }) & \text { kommst } & \text { gabst } & \text { lebtest } \\ \text { er/sie/es }(\text { he/she/it) } & \text { kommt } & \text { gab } & \text { lebte } \\ \text { wir (we) } & \text { kommen } & \text { gaben } & \text { lebten } \\ \operatorname{ihr}(\text { you }) & \text { kommt } & \text { gabt } & \text { lebtet } \\ \operatorname{sie}(\text { they }) & \text { kommen } & \text { gaben } & \text { lebten }\end{array}$

Verb inflection was included in this study along with verb placement, because studies on L1 acquisition of German have shown that there is a strong correlation between verb position and verb form in early German (Clahsen \& Penke, 1992; Meisel, 2011; Poeppel \& Wexler, 1993). The L1 child starts to produce V2 structures only after acquiring the verb categories of person and number, while non-finite forms appear in sentence-final position. Only very rarely do L1 German children 
produce non-finite verb forms in V2 position. This appears to be a domain where L1 development clearly differs from L2 acquisition, since data on L2 German demonstrate that adult as well as child L2 learners frequently produce infinitive forms in finite position (Tran, 2005; Prévost \& White, 2000).

\section{General and specific research questions}

Previous longitudinal studies on child language attrition have shown that erosion effects might appear some months after the dominant environment of the child has changed. Based on these observations, the first general research question of this study is the following:

I- Are morphological and syntactic properties such as verb placement, subject expression, case and gender marking and verb inflection affected by attrition in case of a lack of input? Does the child make grammatical errors in these domains?

If so, we further want to know:

II- When do the first effects of attrition appear? Does the data confirm Kuhberg's (1992) observation that the onset of attrition is set by the fifth month after the loss of input?

III- If the linguistic domains under investigation are in fact affected by attrition, does the child show difficulties in all domains at the same time or is there an order of proficiency decline? Which properties are affected first?

If we look at the linguistic structures under analysis and their characteristics (described in the previous section), we can formulate more specific research questions:

IV- Is the straight correlation between verb placement and finiteness, observed in the acquisition of German, also present in the process of competence decline, i.e., does the child start to make verb placement mistakes at the same time as s/he shows problems with verb inflection? If so, can we observe the same tendency as in L1 German (the use of non-finite forms in sentencefinal position) or is there a resemblance to L2 German (the use of infinitive forms in finite 
positions)?

V- Does the Interface Hypothesis (Sorace, 2004; Tsimpli et al., 2004) apply to child attrition? In other words, does the informant display more difficulties in the domain of subject expression, an interface property, than in the domain of verb placement, a «narrow» syntax feature?

VI- If case marking is vulnerable to attrition, are all cases randomly affected by erosion or does Ana show a tendency to replace the dative case by the nominative or the accusative, such as found in L2 acquisition and, at a sociolinguistic level, in German immigrant communities?

VII- If gender marking is affected by attrition, can we observe a tendency for system reduction (parallel to the simplification of the case system), specifically through the replacement of the neuter gender, which does not exist in Portuguese?

VIII- Finally, do problems with gender assignment appear at the same time as the attrition effects in case marking, i.e., are both nominal domains affected by erosion at the same time?

Method

\section{The participant}

The participant, Ana, is a Portuguese girl who grew up in northern Germany within a Portuguese migrant family and moved back to Portugal when she was nine years old. Ana's parents decided to migrate to Germany when she was 19 months old. Some months after arriving in Germany, Ana entered a public German kindergarten. At the age of seven she was enrolled in the elementary school (Grundschule), after having attended the pre-school (Vorschule) for one year. Ana was in the third grade of the elementary school when her parents got divorced and the mother decided to go back to Portugal with her two children, Ana and her six-year-older brother. By this time Ana was bilingual, speaking Portuguese at home and German at school and with her friends. As it is typical for migrant children, her dominant language was German, i.e., the language of the dominant environment. She felt much more comfortable speaking the majority language and used Portuguese, her heritage language, only when interacting with her parents. Additionally, she attended a heritage language program two hours per week. 
Upon her return Ana enrolled in the third grade at a public school, located in a small village in the north of Portugal. Even though she reported some problems with reading and writing Portuguese, the adjustment to the Portuguese school was not complicated. She made new friends very quickly and was doing very well in school. As a consequence, the L2 input became very limited. Initially Ana continued to speak German to her brother, who was her only German interlocutor in the new Portuguese environment. However, the communication habits between the siblings changed rapidly and three months after her return Ana had entirely abandoned German. The contact with this language was cut off almost completely.

\section{Data collection}

The period of observation includes four recording sessions over 18 months. Data collection started three weeks after the child had moved to Portugal. The second recording took place five months later, when Ana was 9;10 years old. In the third moment of observation, Ana had been living in Portugal for 13 months. The testing period ended 18 months after return, when the participant was almost 11 years old. By this time, she showed severe word retrieval difficulties, which hindered the collection of free spoken data.

Data gathering followed the same methodology applied in the cross-sectional study described in Flores (2010) and (2012). Besides free conversation about topics centered on Ana's everyday life after and before her return, data was also collected through orally elicited production tasks. The participant was asked to comment on pictures and to tell a story. The pictures illustrated scenes related to family, poverty, pollution and health care. Ana was asked to compare her experiences in Portugal and in Germany with regard to these topics. The story was based on five pictures which showed a scene in a park, involving two children and an adult. The participant had to invent a story around these pictures. In the fourth testing session, a production task based on written stimuli was applied, since severe word retrieval difficulties hindered the free production of complete sentences. The first two sessions took place at the interviewer's home, in a quiet room, while the last two sessions took place at the girl's school, during lunch break. A quiet room was also chosen for these 
sessions where the interviewer and the participant could be alone. All sessions were recorded and transcribed in a common text editor.

Table 1 presents a summary of the four testing sessions: the length of residence, the age, the number of sentences counted in each session and the duration of the recordings (in minutes).

\section{Insert here Table 1. Period of observation}

When data collection started (three weeks after Ana's arrival in Portugal), Ana had been attending the third grade at her new school for two weeks. She was given instructions to use only German during the whole session, which she followed rigorously. In this session, Ana's speech was fluent. There was no code-switching and there were no signs of word retrieval difficulties.

Ana had been living in Portugal for five months when the second recording took place. In this session, she was very communicative and happy with the chance to speak German. In the meanwhile the opportunities to use this language had been rare, which she regretted. Her speech was very fluent and she tried to follow the instruction to use only German. However, unlikethe first session, she now occasionally inserted Portuguese words in German sentences. In four out of 108 counted sentences, she used a Portuguese NP (see example (9)). In one utterance she used a Portuguese adjective as predicative.

(9) Da hatten wir so ein Blumen um arco de flores gemacht. (Ana, 2nd session)

there have we such a flower a floral wreath made

'There we made a floral wreath.'

The third recording session took place 13 months after Ana's return to Portugal, when she was 10;06 years old. By this time, Ana's contact with German was almost non-existent. During the summer holidays, shehad received a visit from family members who still lived in Germany, which provided her with the opportunity to use her L2. Nevertheless, Ana's language preferences had 
changed considerably. The girl confessed to feeling much more comfortable speaking Portuguese and avoided using German, even with her German-speaking cousins. In this session, the informant was also instructed to use only German, but this time it was extremely difficult to hold a conversation solely in that language. Ana showed significant word retrieval difficulties. When she did not remember the German words, she often interrupted the sentence or resorted to Portuguese to solve these problems. In this session only 58 sentences were considered for analysis; 18 sentences that were totally produced in Portuguese were excluded. Twenty (out of 58 sentences) were mixed utterances or incomplete sentences. These utterances were considered for the syntactic analysis when at least the verb and the subject were produced in German (see 10a); other cases were included only in the morphological analysis (see 10b).

(10) a. Meine Lehrerin. Mag ich esta. (Ana, 3rd session)

my teacher like I this

'My teacher. I like this one.'

b. Und fez eine Foto ao Mann.

and took a picture of + the man

'(They) took a picture of the man.'

The fourth - and last - recording meeting took place when Ana was 10;11 years old, i.e., 18 months after her return to Portugal. One week before the last session, the interviewer and the informant met in order to continue gathering data in the same way as before. However, during this meeting Ana was not able to speak any German and became very frustrated. Severe word retrieval difficulties hindered production. In order to overcome these problems, in the next meeting, scheduled for the following week, an elicited production task based on written stimuli was applied. The participant was asked to build sentences with words that appeared on a computer screen. The verbs were not inflected and the nouns had no articles, so the task consisted not only in setting the words in the correct order, but also in conjugating the verb and assigning the correct case and 
gender to the noun. In order to ensure the production of different word order patterns (XPVS; Vfinal; vOV), the first element of the sentence was already indicated. The test had a total of 30 sentences: ten should elicit XPVS-sentences (five with a fronted object; five with an adverb phrase in the first position); ten items required the production of embedded sentences (with Vfinal order) and the other ten sentences contained complex verb forms (the Futur and the Perfekt) which called for the vOV pattern. In addition to word order, verb inflection for number and person was also controlled (five items per person/number). Case and gender were elicited through the use of different verbs/prepositions (which required nominative, accusative or dative) and singular nouns (which were feminine, masculine or neuter). Common lexical items were chosen in order to ensure that the participant knew the words. After performing two training items, the participant understood and performed the task without major difficulties. This task did not require the spontaneous activation of the lexicon (which seemed to be Ana's problem), but rather the activation of grammatical knowledge.

\section{Results}

The analysis focuses on the errors made in each session in the aforementioned linguistic domains. The deviations observed in the syntactic and in the morphological domains will be presented separately for each session.

\section{Verb placement}

For the purpose of coding verb placement, all complete sentences in German were counted. The calculation further included mixed sentences, in which Portuguese items were embedded in structures where at least verb and subject were produced in German, as shown in example (10a). The following verb placement patterns were analyzed: i) main clauses beginning with the subject, giving rise to the SVO pattern; ii) main clauses starting with non-subject phrases (adverbs or objects), counted as XPVS-structure; iii) embedded clauses with verb-final position (v-final) and iv) sentences with complex verb forms (vOV-order). Sentences with ungrammatical null subjects 
were excluded for the calculation of patterns i) to iii), since it is not possible to determine verb position without the subject.

The following table shows the rate of the produced word order pattern from session one to four. The results from session four have to be interpreted differently from those of the first three encounters, because the methodology differs from that applied in the previous sessions. For that reason they will be discussed separately.

\section{Insert here Table 2. Word order patterns produced (1st to 4th sessions)}

In the first session half of all counted sentences were SVO-clauses, while $35 \%$ were root sentences that did not start with the subject, thus requiring the XPVS-pattern, which was correctly realized by the informant. Finally, $15 \%$ of the sentences were embedded clauses which required the V-final word order. In this case also, the informant did not make verb placement mistakes. The verb-final property was also visible in the realization of main clauses with complex discontinued verb forms (vOV). In $24 \%$ of all main clauses the non-finite verb form was correctly placed at the end of the sentence. No ungrammatical word order patterns were produced in this first recording session.

As regards verb placement in root and embedded sentences, in the second session, Ana still revealed native-like competence. In all root sentences that did not start with the subject, correct XPVS patterns were employed (45\%); in addition, the complex verb forms matched the grammatical discontinued word order, with the inflected form in the second position and the nonfinite one at the end (19\% vOV-sentences). Compared to the first session, Ana produced fewer embedded sentences ( $8 \%$ against the previous $15 \%)$, yet the verb was correctly placed in sentencefinal position (Vfinal) in all of them.

However, as shown in table 2 , in this session eight (out of 118) counted sentences are not target-like. The ungrammaticality of these sentences is not the consequence of deviations from the verb placement patterns i) to iv), instead it results from subject-verb inversions which are not 
syntactically or pragmatically licensed in German, as shown in example (11).

(11) Mit wem warst du denn da? (Interviewer)

'With whom have you been there?'

*War ich mit die Tante von meine Mutter da. (Ana, 2nd session)

was I with the aunt of my mother there

'I was there with the aunt of my mother.'

[Correct: Ich war mit der Tante meiner Mutter da.]

The sentence «War ich mit die Tante von meine Mutter da» resembles a German topic-drop sentence, i.e., the subject follows the verb (which is in the second sentence position) and the first position is not occupied. In topic-drop sentences, which are current in spoken German, the omitted, fronted object is a topic that can be recovered from the pragmatic context. However, the sentence in (11) is not a topic-drop structure since there is no topic object that could be recovered from the context.

Regarding verb placement, a significant change can be observed if we compare Ana's performance in the second session with the results of the third session (see table 2). If we look at the grammatical sentences, the majority were SVO-sentences. Ana only produced $7 \%$ of XPVSsentences (against $45 \%$ in the previous session). More notable is the fact that she did not produce any subordinate clause with verb-final position. However, the verb-final pattern was still visible in the correct use of vOV-utterances (14\%). Ana became more prone to use verb placement patterns that have a match in Portuguese (SVO) rather than those patterns lacking Portuguese equivalents (e.g., XPVS, Vfinal and vOV), but the latter were not totally lost as she was (still) able to produce them.

However, in this session $43 \%$ of all counted sentences (29 out of 67 ) were syntactically ungrammatical. As regards these deviant occurrences, in addition to the target-deviant inversion constructions already observed in the previous session, the girl started to develop problems with 
verb-second and verb-final positions.

In ten out of the 29 syntactically deviant occurrences, the girl produced ungrammatical XPSVsentences, as shown in example (12).

(12) *Dann der Hund ist Krankenhaus für Tiere. (Ana, 3rd session)

then the dog is hospital for animals

'Then the dog is in the animals' hospital.

[Correct: Dann ist der Hund im Krankenhaus für Tiere.]

Differently from the previous sessions, Ana also began to produce ungrammatical vVOutterances, where the non-finite verb form of complex verbs followed the finite form instead of remaining in final position [see (13)].

(13) *Jemand wird geben ein Hund. (Ana, 3rd session)

someone will give a dog

'Someone will give (him) a dog.'

[Correct: Jemand wird (ihm) ein Hund geben.]

With reference to verb-final position in subordinate clauses, it has already been mentioned that Ana did not produce embedded sentences with verb-final position. In all nine subordinate clauses uttered in this session, the verb was in a higher position instead of remaining in sentence-final order [see example (14)].

(14) ..., *dass die Junge und das Mädchen sich setzen auf ein Stuhl. (Ana, 3rd session) that the boy and the girl them sit on a chair

'That the boy and the girl sit on a chair.'

[Correct: ..., dass der Junge und das Mädchen sich auf ein Stuhl setzen.] 
Table 2 also presents the word order pattern that Ana produced in the experimental task applied during the fourth test session. The results demonstrate that the participant produced both grammatical and ungrammatical sentences. The girl was not able to activate her German in free conversation, but this task, which required mainly the activation of her grammatical knowledge, showed that she retained knowledge of German verb placement rules, since she was able to produce correct word order patterns. However, the production of target-like sentences co-occurred with ungrammatical word sequences (13 out of 30). Out of ten items, Ana produced seven correct XPVS-and three ungrammatical *V3-sentences. Regarding subordinate clauses, four sentences were grammatical (the verb was in sentence-final position) and six were ungrammatical, with the verb following the subject in a non-final sentence position. The co-occurrence of target-like and target-deviant structures was also seen in the production of discontinued verb forms (six vOV against four $*_{\mathrm{vVO}}$-sentences). In this task, Ana once again showed more difficulties in the production of subordinate clauses than V2 sentences.

\section{Subject expression}


The analysis of subject expression included all main and subordinate clauses where the realization of the subject pronoun is obligatory in German. Fixed expressions, where the subject can be omitted in colloquial German, and coordinate clauses, where the co-referent subject of the second clause is not realized (see 15), were excluded. NP-subjects were not counted.

(15) Die sind in Schweiz und können Deutsch reden. (Ana, 1st session)

they are in Switzerland and can German speak

'They are in Switzerland and they speak German.'

Table 3 presents the rate of ungrammatical subject omission from sessions one to three. The test applied in the fourth session did not allow us to analyze subject realization, since the subject was given to the participant and could not be omitted.

\section{Insert here Table 3. Ungrammatical subject omission (1st to 3rd sessions)}

In the first session Ana produced 168 utterances with subject pronouns; the subject was phonetically realized in all contexts. No target-deviant performances were found.

Unlike in the first encounter, in the second session Ana started to omit the subject pronoun in contexts where German requires its realization, as shown in example (16).

(16) Was machst du so am Wochenende? (Interviewer)

'What do you do at the weekend?'

* Ø Spiel mit meine Freunde. $\quad$ (Ana, 2nd session)

play with my friends

'I play with my friends.'

[Correct: Ich spiel(e) mit meinen Freunden.] 
The subject was omitted in seven out of 99 utterances (7\%); five corresponded to the omission of the pronoun ich ('I'), one to es ('it'), and another to the omission of the first-person plural pronoun wir ('we'). In all cases, the omission of the subject pronoun would be grammatical in Portuguese (see (17), the Portuguese equivalence of (16)).

$\varnothing$ Brinco com os meus amigos.

play with the my friends

'I play with my friends.'

Similarly to the previous session, in the third encounter Ana continued to produce sentences with ungrammatical subject omissions, which resemble Portuguese null subject constructions. In six (out of 45) utterances the subject was not realized: in four cases ich ('I') was omitted, and the remaining omissions referred to the third-person plural sie ('they') and to the third-person singular sie ('she') (see (18)).

(18) Vielleicht hat $\varnothing$ ein Kind. (Ana, 3rd session)

probably has a child

'Probably she has a child.'

\section{Case and gender marking}

Gender and case marking were coded separately. For case marking all utterances which should have an overt case form were counted. This includes the definite and indefinite article, pronouns, attributive adjectives and nouns. Contexts which require the use of the genitive were rare, which led to the exclusion of this grammatical case from the analysis. For gender marking the choice of the article and pronoun endings were considered; utterances with omitted articles were excluded. In cases where it was difficult to interpret the produced form as a case or gender mistake, the context 
was used as a cue to allocate the error type. See, for instance, example (19).

(19) Der Ball ist zur Straße gegangen und der Hund ist *hinter der Ball. (Ana, 3rd session) the ball is to+the street gone and the dog is after the ball 'The ball went to the street and the dog is running after the ball.'

In "hinter der Ball" the incorrect use of the masculine article der (instead of dem) can be seen as a case error: der refers to the nominative case, but the dative is required here. Alternatively, it could be interpreted as a gender error: der is also the feminine dative form. However, the previous clause shows that Ana knows the correct gender of Ball, since she uses the correct masculine article. In four cases it was not possible to allocate the error type. These items were excluded from the analysis.

Table 4 shows the rate of case and gender errors in the four sessions.

\section{Insert here Table 4. Case and gender errors (1st to 4th sessions)}

In the first session Ana produced a total of 234 utterances where case was overtly marked. All forms were target-like. Gender was overtly marked in 171 utterances. No gender error was found. This means that in these linguistic domains Ana shows native-like proficiency.

As observed in the syntactic domain, where Ana started to omit subjects and to produce targetdeviant subject-verb inversions, in the second session she started to exhibit problems with morphology. 
The most affected domain was case marking, with case declension errors occurring at a rate of $21 \%$ (40 out of 189). As shown in table 4, most case errors affected the dative, which was replaced by either the accusative (in 15 utterances) or the nominative (in 12 utterances). In seven utterances it was unclear whether the informant used the nominative or the accusative since both forms were identical (see (20)).

(20) *Die gehen zu mein Haus. (Ana, 2nd session)

they go to my ${ }^{\text {NOMACC }}$ house

'They go to my house.'

[Correct: Die gehen zu meinem Haus.]

Besides the incorrect marking of the dative, deviations also randomly affected the use of the accusative, which was replaced by the nominative (six utterances). The nominative was not replaced by other case forms.

Furthermore, some problems were detected with regard to gender marking, but the rate of deviations only amounted to about $4 \%$, corresponding to three occurrences (out of 70 ). In two cases, the neuter was replaced by the masculine (see example (21)), and in one case the feminine was used instead of the masculine (see table 4).

(21) *Ist ein kleiner Schwein. (Ana, 2nd session)

is a small $^{\text {MASC }}$ pig

'It's a little pig.'

[Correct: Es ist ein kleines Schwein.]

Similarly to what happened in the syntactic domain, the number of morphological errors also increased extensively in the third session.

The most problematic property of German morphology continued to be case marking. The 
error rate increased to $62 \%$ in this session. As shown in table 4 , in the majority of the ungrammatical contexts, the dative was replaced by the nominative or the accusative case (see (22)). In no context was the dative used instead of the other cases.

(22) Ich sehe viel Müll in die Straße. (Ana, 3rd session)

I see much garbage on the street

'I see lots of garbage on the street.'

[Correct: Ich sehe viel Müll in/auf der Straße.]

The error rate in the domain of gender marking increased considerably as well; in $38 \%$ of all utterances the noun was marked with a wrong gender. Interestingly the distribution of the error types (see table 4) shows no explicit tendency to reduce the German three-gender system to a simpler masculine/feminine system, such as in Portuguese. Actually, the most common error (nine utterances) consisted in using the neuter instead of the masculine or the feminine, as in example (23).

(23) *Das Mann ist braun. (Ana, 3rd session)

the $e^{N E U}$ man is brown

'The man is brown.'

[Correct: Der Mann ist braun.]

With reference to case marking, 22 contexts which required overt case marking were included in the sentence production task applied in the fourth session. In 12 cases Ana did not choose the correct case form (55\%). Again, the dative case was the most affected. In seven out of the nine dative contexts, it was replaced by nominative or accusative forms. Four ungrammatical constructions corresponded to contexts where the accusative was replaced by the nominative (three utterances) and by the dative (one utterance). In one case the nominative was replaced by the 
accusative.

Additionally the rate of deviation in gender marking was similar to the error rate found in the previous session: nearly $45 \%$ (ten out of 22). Gender assignment continued to be random since there was no clear preference for one specific gender and, in particular, there was no tendency for favoring the use of the masculine or the feminine gender instead of the neuter (see the error distribution in table 4).

\section{Verb inflection}

Regarding verb inflection, the analysis focused only on the use of the correct inflection for person and number in finite contexts. Three options were considered for coding; i) the use of the correct inflection form; ii) the use of an incorrect person/number morpheme; iii) the use of the infinitive instead of a finite form. Other errors in verb morphology (such as the incorrect production of irregular forms) were not considered.

Table 5 presents the results for all four testing sessions.

\section{Insert here Table 5. Verb form in finite contexts (1st to 4th sessions)}

As shown in table 5, Ana inflects the verb correctly for number and person in all finite contexts in the first as well as in the second session.

Contrary to the previous sessions, in the third encounter Ana started to show problems with verb inflection. In 17\% (11 out of 65) of all finite contexts she used the infinitive form instead of inflecting the verb (see (24)). In all cases, the infinitive was substituted for the third-person singular form. In two utterances a wrong inflection form was used (the third-person instead of the firstperson singular).

(24) ..., weil meine Mutter arbeiten acht Uhr. (Ana, 3rd session)

because my mother work $^{\mathrm{INF}}$ eight o'clock. 


\section{'because my mother works until eight o'clock. \\ [Correct: ..., weil meine Mutter bis acht Uhr arbeitet.]}

The same tendency was observed in the fourth session: in the majority of the contexts the participant used the correct verb inflection $(70 \% ; 21 / 30)$. In the remaining $30 \%$ of the contexts, Ana used the verb in its non-inflected form: in three cases she used the infinitive instead of the first person, in two cases instead of the second person and in four cases instead of the third person. However one must bear in mind that, in the elicitation task, the verb was presented in its infinitive form, which could have influenced Ana's performance.

\section{Summary of the results}

Figure 1 presents the development of the error rate from the first up to the fourth session in all of the contexts under analysis.

In short, the first target-deviant productions occurred at the second session (five months after return) in interface properties (subject realization and pragmatically-deviant word order) and in the case system. The other properties remained unaffected by attrition until session three (13 months later). In this session gender marking was significantly affected. Also verb placement showed deviations. It should be noted that verb placement errors appeared at the same time as verbal morphology (person and number marking) was affected. Although the fourth session was based on written stimuli, it reflected a similar tendency to that identified in the previous session. Ana produced both grammatical and ungrammatical constructions in all investigated domains.

After 18 months without regular exposure to German, all analyzed areas became affected by attrition. In no case, however, was there a total loss of knowledge. Even when Ana experienced extreme word retrieval difficulties, in the fourth session, she was still able to produce correct grammatical constructions.

Insert here Figure 1. Development of the error rate (1st to 4th sessions) 


\section{Discussion}

First and foremost, this study confirms the results of previous research on the development of child language after a change of input. Most longitudinal studies report the emergence of attrition effects some months after the bilingual child has experienced loss of contact with one language, especially in the case of migrant returnees. The informant of this study, who was highly proficient in her L2 German when she moved to Portugal, started to show attrition effects five months after having immersed herself in the Portuguese environment. The same was observed by Kuhberg (1992) in his L2 attrition study on Turkish-German returnees. This observation positively answers the first research question of this study and reinforces the idea that after its acquisition, linguistic knowledge needs to stabilize in the speaker's mind in order to become immune to loss (Flores, 2010). Only sufficient exposure seems to ensure this stabilization process.

A second important remark is that not all linguistic areas are affected by attrition at the same time. In fact, some areas show effects of attrition before others. In the syntactic domain, when Ana starts to produce ungrammatical constructions five months after return, the deviations begin by affecting only subject realization and pragmatically-linked word order, but not core syntax properties such as verb placement. It is not until a second stage of attrition (after one year) that the participant demonstrates difficulties with verb position. As far as subject realization is concerned, Ana seems to transfer into German the Portuguese omission conditions. Regarding the pragmatically deviant constructions, these structures resemble topic-drop sentences, but without a dropped topic. In both cases, the ungrammaticality seems to be the result of a mismatch between syntactic and pragmatic rules. It appears that Ana has difficulties in joining syntactic rules with pragmatic conditions. These difficulties show that properties set at the interface between syntax and pragmatics are indeed affected faster by lack of input than other «narrower» syntactic domains. This observation indicates that also in the context of child attrition there might be differences between core syntax and interface properties, as proposed by Sorace and colleagues (Sorace, 2004; Tsimpli et al., 2004) for bilingual language acquisition. 
Furthermore, this study shows that certain grammatical errors appear broadly at the same time, suggesting that there might be a relationship between the emergence of attrition effects in different areas of linguistic knowledge. Ana started to demonstrate difficulties in verb placement at the same time as she started to use non-inflected verb forms, almost one year after leaving the dominant German environment. Studies on L1 acquisition of German have provided evidence that there is a close correlation between the acquisition of verb inflection and verb placement in the acquisition process. For instance, only after acquiring the verb categories of person and number are German L1 speakers able to produce V2 sentences (Clahsen, 1986; Meisel, 1994). It is, therefore, very curious to note that the informant produced deviant word order patterns at the same time as she began to struggle with person-number inflection. However, differently from L1 children in early stages of acquisition, Ana uses non-inflected forms in finite positions, resembling error patterns produced by L2 acquirers (Tran, 2005; Prévost \& White, 2000). The data thus suggest that, in the decline process, speakers may regress to an earlier stage of acquisition and start to produce structures that are typical of this acquisition stage. In this case, the relationship between verb inflection and word order is not as evident as in L1 acquisition, where it can be claimed that the child only acquires one property after having acquired the other. Regarding the attrition process, it is not possible to clearly state that the child loses one property after having lost the other. It is almost consensual among researchers that attrition is not the inverse of acquisition, i.e., attrition does not follow the acquisition path in the inverse order, as has been proposed in Jakobson's regression hypothesis (Jakobson, 1941). Even though this correlation is not as evident as in the acquisition process, the hypothesis that it also holds for the decline of language proficiency cannot be disregarded.

As for morphology, the results show that case marking is highly susceptible to attrition. Ana produced high rates of case errors very early on, i.e., five months after leaving Germany, when other grammatical features were still very stable. This observation matches the results of other studies, which identify case marking as a highly permeable domain in language attrition (Jordens et al., 1989; Polinsky, 1997). From the second session onward, Ana showed a clear tendency to avoid the dative case and to replace it with the accusative or nominative. It is interesting to note that the 
same tendency is described in studies on language change in German immigrant communities in the US, Brazil or Australia (Altenhofen, 1996; Boas, 2009; Clyne, 1991). This confirms the direct relationship between individual erosion of linguistic knowledge and language change in a wider community. Language change in a speech community starts with individual variation, which in turn is the consequence of changes in the input conditions. The reason for the loss of the dative case (instead of the accusative case), on the other hand, can be found in the nature of the case system per se and its acquisition process. Studies by Clahsen (1986) and Tracy (1984), for instance, have shown that in L1 German the dative case is acquired much later than the nominative and the accusative. After acquiring these latter cases, the German child goes through a stage where s/he uses the accusative in dative contexts and only later does s/he start to distinguish between the accusative and the dative cases. It is worth noticing, however, that German children never overuse the dative case. Thus, it seems that language attrition affects the case which is acquired at later stages of L1 development.

Finally, it is shown that gender marking, too, is affected by attrition, but later than the case system. Significant gender marking errors were only visible at the third recording session. In contrast to case marking, however, the three-gender system did not show a tendency for reduction. Instead, attrition was manifested in arbitrary gender assignment, a tendency also observed in Schmid (2002). This observation suggests that cross-linguistic influence might play a minor role in this domain. The fact that Portuguese, the stronger language, only has two genders - masculine and feminine - did not reinforce the use of both these genders in German, leading to the loss of the neuter. What happened was that Ana continued to use the three genders but she had difficulties in choosing the correct one. These difficulties can be attributed to increasing lexical retrieval difficulties. Since gender assignment is very opaque in German, lacking explicit morphological and phonetic cues, it is acquired together with the lexicon. Thus, problems with lexical access seem to generate difficulties in gender assignment.

Coming back to the role of cross-linguistic influence in language attrition, it is very difficult to make a clear-cut distinction between both processes. Indeed, it is often unclear if the bilingual 
attriter starts to produce deviant structures in the attrited language due to the influence of the dominant one (in this case, attrition would be the outcome of cross-linguistic influence) or if the process of decline somehow reflects a universal tendency that does not depend on the presence of the other language. Ana's problems with verb placement are representative of this indistinctness. For instance, it is almost impossible to determine if the production of ungrammatical V3-sentences is directly influenced by Portuguese, an SVO-language, or if it is the outcome of a languageindependent tendency to resort to unmarked structures (if we see V2 as a marked feature in the line of Platzack, 1996). More comparable studies with different language pairs (e.g. two V2-languages) are needed in order to achieve a better understanding of this issue.

The present paper also reinforces the assumption that bilingual children need uninterrupted exposure to both languages in order to retain their bilingual competence. If the speaker loses continued contact with one language at the age of nine, such as in the case of Ana, attrition effects might emerge a few months after the change of input. One could further hypothesize that the process of decline is even more severe in the case of L2 attrition. In Ana's case, the attrition effects could be attributed to the fact that she had acquired German as a second language, even though it had been acquired at early stages of development and had become her dominant language before return. It should be noted that in other studies on bilingual returnees (see introductory sections) the language under attrition had also been the speakers' L2. Therefore it might be reasonable to assume that the child had probably already acquired the structures under investigation (since she showed native-like performance in the first session), but this knowledge was still not sufficiently stabilized in her mind.

To conclude, attrition affects various morphosyntactic areas, even though not to the same extent and not necessarily at the same time. Nevertheless, the greatest challenge for child attriters seems to be lexical retrieval. After 18 months lacking German input, Ana was not able to remember the most common words, such as 'Haus' (house) or 'Baum' (tree). However, when the lexicon was provided, the girl managed to activate her grammatical knowledge, although she delivered both grammatical and ungrammatical structures. This shows that the bilingual attriter produces deviant 
utterances, but does not lose his/her grammatical knowledge completely. 


\section{References}

Ahrenholz, B. (ed.) (2006). Kinder mit Migrationshintergrund-Spracherwerb und Fördermöglichkeiten. Freiburg i. Br.: Fillibach.

Altenhofen, C. (1996). Hunsrückisch in Rio Grande do Sul: Ein Beitrag zur Beschreibung einer deutschbrasilianischen Dialektvarietät im Kontakt mit dem Portugiesischen. Stuttgart: Steiner Verlag.

Bingham, S. (2007). When daddy leaves home. Minority L1 attrition in a primary bilingual child. Japan Journal of Multilingualism and Multiculturalism 13, 26-43.

Boas, H. (2009). Case loss in Texas German. The influence of semantic and pragmatic factors. In J. Barðdal \& S. Chelliah (eds.), The role of semantics and pragmatics in the development of case (pp. 347-373). Amsterdam/ Philadelphia: Benjamins.

Clahsen, H. (1986). Verb inflection in German child language: Acquisition of agreement markings and the functions they encode. Linguistics 24, 79 - 121. doi:10.1515/ling.1986.24.1.79

Clahsen, H., Meisel, J.M. \& Pienemann, M. (1983). Deutsch als Zweitsprache: Der Spracherwerb ausländischer Arbeiter. Tübingen: Narr

Clahsen, H. \& Penke, M. (1992). The acquisition of agreement morphology and its syntactic consequences: New evidence on German child language from the Simone-Corpus. In J. Meisel (ed.), The acquisition of verb placement: Functional categories and V2 phenomena in language acquisition (pp. 181-223). Dordrecht: Kluwer.

Clyne, M. (1991). Community languages: The Australian experience. Cambridge: CUP.

Flores, C. (2010). The effect of age on language attrition: Evidence from bilingual returnees. Bilingualism: Language and Cognition 13 (4), 533-546. doi:10.1017/S136672890999054X

Flores, C. (2012). Differential effects of language attrition in the domains of verb placement and object expression. Bilingualism: Language and Cognition 15 (3), 550-567. doi:10.1017/S1366728911000666

Hansen, L. (ed.) (1999). Second language attrition: Evidence from Japanese contexts. New York: Oxford University Press 
Hyltenstam, K., Bylund, E., Abrahamsson, N. \& Park, H-S. (2009). Dominant-language replacement: The case of international adoptees. Bilingualism: Language and Cognition 12 (2), 121-140. doi:10.1017/S1366728908004008

Jakobson, R. (1941). Child language, aphasia and phonological universals. Translated edition: 1968. The Hague: Mouton.

Jordens, P., de Bot, K. \& Trapman, H. (1989). Linguistic aspects of regression in German case marking. Studies in Second Language Acquisition 11 (2), 179-204. doi:10.1017/S0272263100000607

Kang, S.-G. (2011). English attrition in Korean-English bilingual children. PhD dissertation. University of Hawai.

Kaufman, D. \& Aronoff, M. (1991). Morphological disintegration and reconstruction in first language attrition. In H. W. Seliger \& R. M. Vago (eds.), First language attrition (pp. 175188). Cambridge, UK: CUP.

Kuhberg, H. (1992). Longitudinal L2-attrition versus L2-acquisition in three Turkish children empirical findings. Second Language Research 8 (2), 138-154. doi: $10.1177 / 026765839200800203$

Meisel, J.M. (1994). Getting FAT. In J.M. Meisel (ed.), Bilingual First Language Acquisition. French and German Grammatical Development (pp. 89-129). Amsterdam: John Benjamins.

Meisel, J.M. (2011). First and second language acquisition. Cambridge: CUP.

Montrul, S. (2008). Incomplete acquisition in bilingualism: Re-examining the age factor. Amsterdam: John Benjamins.

Olshtain, E. (1986). The attrition of English as a second language with speakers of Hebrew. In K. Weltens, K. de Bot \& T. van Els (eds.), Language Attrition in Progress (pp. 187-204). Dordrecht: Foris.

Platzack, C. (1996). The initial hypothesis of syntax: A minimalist perspective on language acquisition and attrition. In H. Clahsen (ed.), Generative perspectives on language acquisition (pp. 369-414). Amsterdam: John Benjamins. 
Poeppel, D. \& Wexler, K. (1993). The full competence hypothesis of clause structure in early German. Language 69, 1-33. doi:10.2307/416414

Polinsky, M. (1997). American Russian: Language loss meets language acquisition. Formal approaches to Slavic linguistics 4. Ann Arbor: Michigan Slavic Publications, 370-406.

Polinsky, M. (2011). Reanalysis in adult heritage language. New evidence in support of attrition. Studies in Second Language Acquisition 33, 305-328. doi:10.1017/S027226311000077X

Prévost, P. \& White, L. (2000). Missing surface inflection or impairment in second language acquisition? Evidence from tense and agreement. Second Language Research 16, 103-133. doi:10.1191/026765800677556046

Reetz-Kurashige, A. (1999). Tracking returnees' retention of English speaking skills: Changes in verb usage over time. In L. Hansen (ed.), Second language attrition: Evidence from Japanese contexts (pp. 21-58). New York: Oxford University Press.

Rothweiler, M. (2006). The acquisition of V2 and subordinate clauses in early successive acquisition of German. In C. Lleó (ed.), Interfaces in Multilingualism: Acquisition, Representation and Processing (pp. 91-113). Amsterdam: John Benjamins.

Schmid, M. (2002). First language attrition, use and maintenance: The case of German Jews in anglophone countries. Amsterdam/Philadelphia: Benjamins.

Seliger, H. W. (1996). Primary language attrition in the context of bilingualism. In W.C. Ritchie \& T.K. Bhatia (eds.), Handbook on Second Language Acquisition (pp. 605-626). San Diego: Academic Press.

Sorace, A. (2004). Native language attrition and developmental instability at the syntax-discourse interface: Data, interpretations and methods. Bilingualism: Language and Cognition 7, 143-45. doi:10.1017/S1366728904001543

Szagun, G. (2004). Learning by ear: on the acquisition of case and gender marking by Germanspeaking children with normal hearing and with cochlear implants. Journal of Child Language 31, 1-30. doi:10.1017/S0305000903005889 
Tomiyama, M. (2000). Child second language attrition: a longitudinal case study. Applied Linguistics 21 (3), 304-332. doi:10.1093/applin/21.3.304

Tracy, R. (1984). Fallstudien. Überlegungen zum Erwerb von Kasuskategorie und Kasusmarkierung. In H. Czepluch \& H. Jansen (eds.), Syntaktische Struktur und Kasus-relationen (pp. 271-313). Tübingen: Narr.

Tran, J. (2005). Word order and verb inflection in English-speaking children's L2 acquisition of German V2. University of Hawaii Working Papers in Linguistics 36, 1-33

Tsimpli, I., Sorace, A., Heycock, C. \& Filiaci, F. (2004). First language attrition and syntactic subjects: A study of Greek and Italian near-native speakers of English. International Journal of Bilingualism 8 (3), 257-277. doi:10.1177/13670069040080030601

Turian, D. \& Altenberg, E. (1991). Compensatory strategies of child first language attrition. In H. W. Seliger \& R. M. Vago (eds.), First language attrition (pp. 207-226). Cambridge, UK: CUP.

Wegener, H. (1995a). Das Genus im DaZ-Erwerb. Beobachtungen an Kindern aus Polen, Rußland und der Türkei. In B. Handwerker (ed.), Fremde Sprache Deutsch (pp. 1-24). Tübingen: Narr.

Wegener, H. (1995b). Kasus und Valenz im natürlichen DaZ-Erwerb. In L. Eichinger \& H.W. Eroms (eds.), Dependenz und Valenz (pp. 337 - 356). Hamburg: Buske.

Yoshitomi, A. (1999). On the loss of English as a second language by Japanese returnee children. In L. Hansen (ed.), Second language attrition in Japanese contexts (pp. 80-111). New York: Oxford University Press. 
Table 1. Period of observation

\begin{tabular}{|c|c|c|c|c|}
\hline Sessions & $\begin{array}{l}\text { LOR } \\
\text { (after return) }\end{array}$ & $\begin{array}{l}\text { Age } \\
\text { (year; month) }\end{array}$ & $\begin{array}{l}\text { Counted } \\
\text { sentences }\end{array}$ & $\begin{array}{l}\text { Length of } \\
\text { recording } \\
\text { (in minutes) }\end{array}$ \\
\hline 1st session & 3 weeks & $9 ; 05$ & 186 & 38 \\
\hline 2nd session & 5 months & $9 ; 10$ & 108 & 29 \\
\hline 3rd session & 13 months & $10 ; 06$ & 58 & 21 \\
\hline 4th session & 18 months & $10 ; 11$ & 30 & 16 \\
\hline
\end{tabular}


Table 2.Word order patterns produced (1st to 4th sessions)

\begin{tabular}{llllll}
\hline & SVO & XPVS & Vfinal & vOV & ungramm \\
\hline 1st session & $107 / 214(50 \%)$ & $75 / 214$ & $28 / 214$ & $51 / 214$ & $0 / 214$ \\
& & $(35 \%)$ & $(15 \%)$ & $(24 \%)$ & $(0 \%)$ \\
\hline 2nd session & $36 / 110$ & $50 / 110$ & $9 / 110$ & $22 / 118$ & $8 / 118$ \\
& $(33 \%)$ & $(45 \%)$ & $(8 \%)$ & $(19 \%)$ & $(7 \%)$ \\
\hline 3rd session & $25 / 58$ & $4 / 58$ & $0 / 58$ & $9 / 67$ & $29 / 67$ \\
& $(43 \%)$ & $(7 \%)$ & $(0 \%)$ & $(14 \%)$ & $(43 \%)$ \\
\hline
\end{tabular}


Table 3. Ungrammatical subject omission (1st to 3rd sessions)

\begin{tabular}{llllll}
\hline & $\begin{array}{l}\text { ungrammatical } \\
\text { subject omission } \\
\text { (total) }\end{array}$ & 1st person & 1st person & 3rd person & 3rd person \\
& & ich & wir & singular & plural \\
& & 0 & 0 & 0 & sie \\
\hline 1st session & $0 / 168(0 \%)$ & 5 & 1 & 1 & 0 \\
\hline 2nd session & $7 / 99(7 \%)$ & 4 & 0 & 1 & 1 \\
\hline 3rd session & $6 / 45(13 \%)$ & & & & \\
\hline
\end{tabular}


Table 4. Case and gender errors (1st to 4th sessions)

\section{Case errors}

\section{Gender errors}

\begin{tabular}{|c|c|c|c|c|c|c|c|c|c|c|c|}
\hline & Total & & & Erro & type & & & Total & & Error type & \\
\hline & & $\begin{array}{l}\text { dat» } \\
a c c\end{array}$ & $\begin{array}{l}\text { dat» } \\
\text { nom }\end{array}$ & $\begin{array}{l}\text { dat» } \\
\text { nom/ } \\
\text { acc }\end{array}$ & $\begin{array}{l}\text { acc» } \\
\text { nom }\end{array}$ & $\begin{array}{l}\text { nom» } \\
\text { acc }\end{array}$ & $\begin{array}{l}a c c » \\
d a t\end{array}$ & & $\begin{array}{l}\text { neu» } \\
\text { masc/fem }\end{array}$ & $\begin{array}{l}\text { masc/fem» } \\
\text { neu }\end{array}$ & $\begin{array}{l}\text { fem» masc } \\
\text { mas » fem }\end{array}$ \\
\hline $\begin{array}{l}\text { 1st } \\
\text { session }\end{array}$ & $\begin{array}{l}0 / 234 \\
(0 \%)\end{array}$ & 0 & 0 & 0 & 0 & 0 & 0 & $\begin{array}{l}0 / 171 \\
(0 \%)\end{array}$ & 0 & 0 & 0 \\
\hline $\begin{array}{l}\text { 2nd } \\
\text { session }\end{array}$ & $\begin{array}{l}40 / 189 \\
(21 \%)\end{array}$ & 15 & 12 & 7 & 6 & 0 & 0 & $\begin{array}{l}3 / 70 \\
(4 \%)\end{array}$ & 2 & 0 & 1 \\
\hline $\begin{array}{l}\text { 3rd } \\
\text { session }\end{array}$ & $\begin{array}{l}42 / 68 \\
(62 \%)\end{array}$ & 14 & 14 & 6 & 7 & 1 & 0 & $\begin{array}{l}18 / 48 \\
(38 \%)\end{array}$ & 5 & 9 & 4 \\
\hline $\begin{array}{l}\text { 4th } \\
\text { session }\end{array}$ & $\begin{array}{l}12 / 22 \\
(55 \%)\end{array}$ & 4 & 2 & 1 & 3 & 1 & 1 & $\begin{array}{l}10 / 22 \\
(45 \%)\end{array}$ & 3 & 4 & 3 \\
\hline
\end{tabular}


Table 5. Verb form in finite contexts (1st to 4th sessions)

\begin{tabular}{llll}
\hline & correct inflection & incorrect inflection & infinitive \\
\hline 1st session & $216 / 216$ & $0 / 216$ & $0 / 216$ \\
& $(100 \%)$ & $(0 \%)$ & $(0 \%)$ \\
\hline 2nd session & $115 / 115$ & $0 / 115$ & $0 / 115$ \\
& $(100 \%)$ & $(0 \%)$ & $(0 \%)$ \\
\hline 3rd session & $25 / 65$ & $2 / 65$ & $11 / 65$ \\
& $(81 \%)$ & $(3 \%)$ & $(17 \%)$ \\
\hline 4th session & $21 / 30$ & $0 / 30$ & $9 / 30$ \\
& $(70 \%)$ & $(0 \%)$ & $(30 \%)$ \\
\hline
\end{tabular}




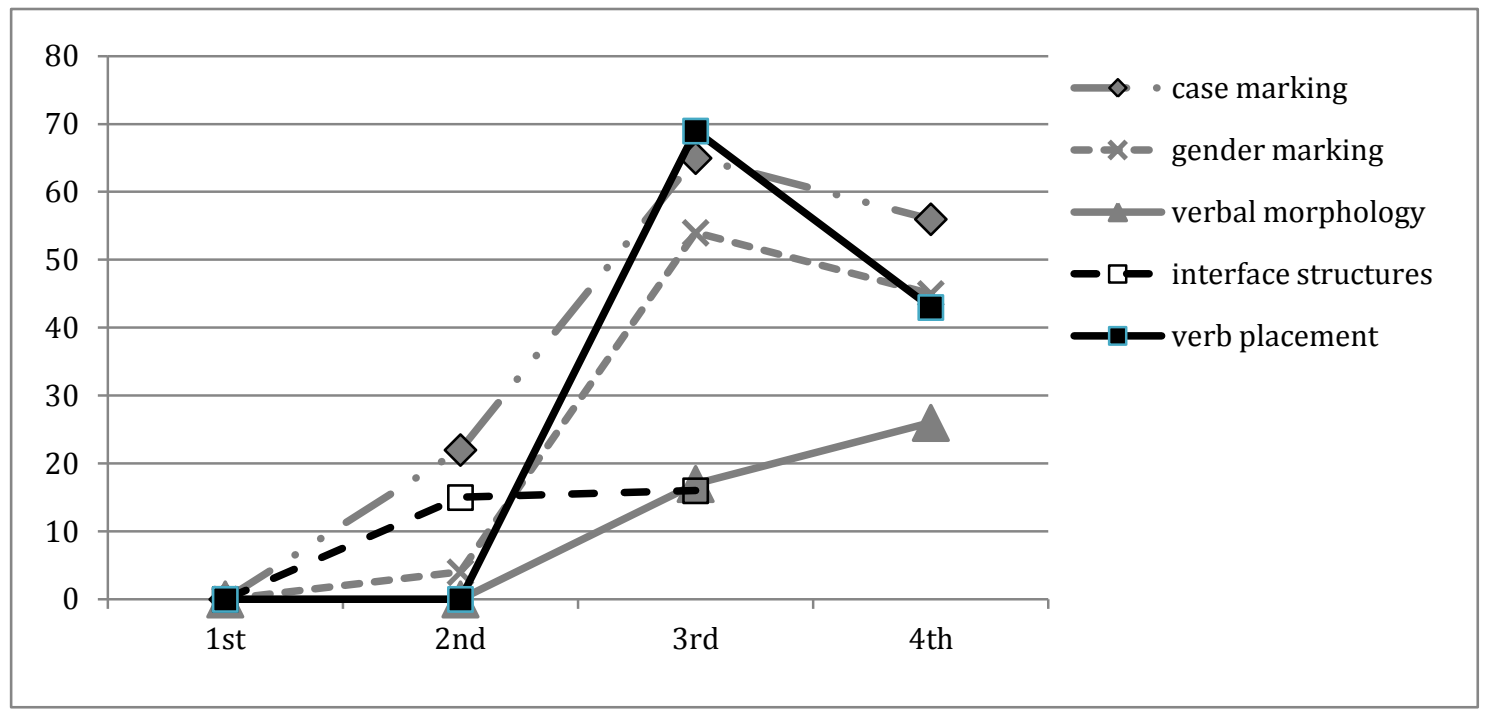

Figure 1. Development of the error rate (1st to 4th sessions) 